\title{
Muslim Personal Laws and the Accommodation of Minorities: The Need to Better Balance Individual Rights and Group Autonomy in Singapore
}

\author{
Noor Aisha Abdul Rahman*(i)
}

(Received 16 August 2019; accepted 28 August 2019)

\begin{abstract}
The accommodation of religious personal law systems is an issue that has arisen in many countries with significant Muslim minorities. The types of accommodations can range from direct incorporation into the state legal system to mere recognition of religious tribunals as private organs. Different forms of accommodation raise different types of legal, social, and political issues. Focusing on the case of Singapore, I examine one form of accommodation which entails the direct incorporation of this law regulating marriage, divorce, and inheritance for Muslims into the state system. Administered by the Administration of the Muslim Law Act, 1966, the Muslim law binds Muslims unless they abjure Islam. The resulting pluralistic legal system is deemed necessary to realize the aspirations of and give respect to the Muslim minority community, the majority of whom are constitutionally acknowledged as indigenous to the country. This Article examines the ramifications of this arrangement on the rights and well-being of members of this community in the context of change. It argues that, while giving autonomy to the community to determine its personal law and advancing group accommodation, the arrangement denies individuals the right to their choice of law, a problem exacerbated by traditionalism and the lack of democratic process in this domain. Consequently, the Muslim law pales in comparison to the civil law for non-Muslims. The rise of religious resurgence since the 1970s has but compounded the problem. How the system can accommodate the Muslim personal law without compromising the rights of individual Muslims is also discussed.
\end{abstract}

Keywords: Legal pluralism; Muslim personal law; Singapore; Syariah law and human rights; Islamic law

\section{A. Introduction: Muslim Personal Law and the Accommodation of Religious Minorities}

The accommodation of Muslim personal law in a general legal system is an issue that affects not only jurisdictions in the East but also in the West. Questions as to whether Sharia should be recognized and incorporated into the legal systems of liberal democracies in the West has attracted significant debate, sometimes in rather virulent terms. ${ }^{1}$ Incorporating religious personal law systems can be argued based on the need for accommodation of minorities, or even based on religious freedom. The range of accommodation can range from direct incorporation into the state legal system to mere recognition of religious tribunals as private organs. Different forms of accommodation raise different types of legal, social, and political issues. In this Article, I examine one form of accommodation, which entails the direct incorporation of Muslim personal law into the state

\footnotetext{
${ }^{\star}$ Noor Aisha Abdul Rahman is the Head of the Department of Malay Studies at the National University of Singapore.

${ }^{1}$ For an examination of the range of contestation, see Rex Ahdar \& Nicholas Aroney, The Topography of Shari'a in the Western Political Landscape, in SHARI'A In ThE West (Rex Ahdar \& Nicholas Aroney eds., 2010). 
system. This arrangement results in a pluralistic legal system, which is said to be necessary to realize the aspirations of a religious minority.

The administration of Muslim personal law in Singapore, however, has adverse implications. In particular, it limits the rights of members of the community to choose the law applicable to them due to the compulsory nature of the regime. At the same time, while giving the community autonomy over the content of the law serves to advance group accommodation, this has the effect of relegating the determination of substantive Muslim law to the prerogative and monopoly of theologians. Such an arrangement therefore could result in the dominance of traditional interpretations of Muslim personal law, which is further exacerbated by rigidity in the mode of thinking amongst dominant groups. The Singapore case study serves to illustrate these issues in order to engage with the broader conversation about the best way to accommodate religious minorities within the legal system.

\section{B. Singapore's Muslim Community and the Management of Muslim Personal Law}

Predominantly of Malay ethnicity, the Muslims in Singapore comprise 14\% of the total population and are by far the largest minority group in the country. ${ }^{2}$ How the state manages the Muslim personal law and legal institutions of the community cannot be separated from its approach to managing the religious affairs of the community. Though deemed as citizens of the state subjected, for the most part, to a common system of law as their non-Muslim counterparts, Muslims are also recognized as a distinct community from their non-Muslim counterparts. This unique status of the community as Muslims and as citizens is clearly reflected not only in specific institutions devised to administer the religious affairs of the community, but also in the dual system of laws regulating family relations in Singapore. While non-Muslims are subjected to the Women's Charter of 1961, Muslims are bound by their personal law administered by the Administration of the Muslim Law Act of 1966 (hereinafter "AMLA") in the areas of marriage, divorce-including ancillary issues-and inheritance, unless they abjure Islam. This accommodation of Muslim personal law has a constitutional basis-Article 12(1) of the Constitution of the Republic of Singapore which guarantees that "[a]ll persons are equal before the law and entitled to equal protection of the law" and provides an exception for the Muslim personal law in Subsection (3), which states that " $t]$ his article does not invalidate or prohibit -(a) any provision regulating personal law."

The Singapore model of and approach to managing the religious affairs and institutions of the community, including the Muslim personal law, have been generally evaluated positively by scholars who see this as part of the wider acceptance of the state for religion to play a constructive role in forging a harmonious and cohesive society. The state's approach has also been perceived as accommodating Muslims' religious freedom and obligations, including observing their religious law while bound to other national laws in common with non-Muslims. The AMLA, for instance, has been deemed to embody religious and legal pluralism within a secular democracy in which the state supports and provides pecuniary and other forms of support for Muslim religious institutions. It has also been seen as a model of "how a secular democracy negotiates the need to accommodate and reconcile the spheres of law and religion" that reflects "the place of a minority Muslim community within a larger multi-religious society where the law of the land is not based on any religion."' It is also seen to "balance the ability of a religious minority to enjoy its private space and practice its own religious beliefs without becoming alienated from society at large." It is said to allow Muslims the "privilege of invoking Islamic law when it comes to some matters of personal law," though they stand together with

\footnotetext{
${ }^{2}$ General Household Survey, SING. DEP'T. STAT. (2015), https://www.singstat.gov.sg/-/media/files/publications/ghs/ghs2015/ indicators.pdf.

${ }^{3}$ Kevin Tan \& Thio Li-Ann, 50 Constitutional Moments that Define a Nation 73 (2015).

${ }^{4} I d$.
} 
other Singaporeans as being equal before the law. ${ }^{5}$ The government's good intentions and extremely cautious approach in obtaining community elite's endorsement for the AMLA and its development, as well as serious deliberations that went into its making, have also been highlighted to convey the state's respect for accommodating the religious law of its minority community. ${ }^{6}$

It is certainly undeniable that the approach grants Muslims autonomy and freedom to practice its religious $\mathrm{law}^{7}$ and provides support for these by way of the key Muslim institutions administered by the AMLA - the Religious Council of Singapore (MUIS), the Registry of Muslim Marriage (ROMM), and the Syariah Court (SYC). This has in part been conditioned by recognition of the special position of the Malays as the indigenous people of Singapore stipulated in Article 152 of the Constitution and the government's commitment to its obligation "to protect, safeguard, support, foster and promote" their religious interests. Indeed, parliamentary debates on the bill reflected careful consideration that went into enacting the AMLA. The AMLA was expected to keep abreast with legal reforms in the larger Muslim world aimed at improving the status of women in marriage while buttressing the family. ${ }^{8}$ It was entirely left to the Muslim community to decide on the substantive law and its changes, if required.

What tends to be consistently overlooked, however, is the impact of this arrangement on the rights of members of the community to the choice of law applicable to them as citizens. By virtue of this approach, all who profess Islam are bound by the Muslim law based on birth right or the moment they accept the religion, regardless of their preference. ${ }^{9}$ The adverse impact of such an arrangement as this on the rights of members of a community has been the subject of critical attention in studies on legal pluralism. One scholar, for instance, has noted that though pragmatic and well meaning, granting autonomy to the community to determine its law based on its culture or religion has resulted in the systematic legal maltreatment of specific groups such as women where the laws are incongruent with gender equality. ${ }^{10}$

The arrangement of leaving the community to determine the Muslim law has, in effect, relegated it to the purview of the community's religious elite who are mainly officially appointed. Unlike the case of family law for non-Muslims determined by the parliamentary process, the Muslim law is monopolized by theologians whom even the Muslim political elites defer to. The selection and determination of the substantive law lie largely in their hands, and they are not subjected to transparent and participatory democratic processes. Essentially, the law applied is drawn largely from selected rulings and interpretations of classical legal savants of the past from the Shafie school. These are deemed representative and definitive despite competing traditions within and beyond the same jurisprudential school. The state's over-reliance on this dominant group aggravates the problem.

The problem is compounded by rigidity in their mode of thinking on the Muslim law that strongly depicts the salient traits of traditionalism. ${ }^{11}$ Such a mode of thought is characterized by the emotive tendency to perceive the Muslim law selected and applied as supra-temporal and beyond revaluation. The law devised by classical scholars based on religious sources and traditions in pre-modern, pre-industrial societies, structurally different from contemporary Malay

\footnotetext{
${ }^{5}$ Ahmad Nizam bin Abbas, The Islamic Legal System in Singapore, 21 PAC. Rim L. \& Pol’y. J. 163 (2014).

${ }^{6}$ Tuty Raihanah Mostarom, The Singapore Ulama: Religious Agency in the Context of a Strong State, 42 AsIAN J. Soc. SCI. 561 (2014).

${ }^{7}$ For a discussion on Singapore's management of religion, refer to Eugene Tan, Keeping God in Place: The Management of Religion in Singapore, in ReLIGIOUS DIVERSITY IN SINGAPORE 55-82 (Lai Ah Eng ed., 2008).

${ }^{8}$ See Parliament of Singapore, Report on the Select Committee on the Administration of Muslim Law Bill (1966). See also Singapore Parliamentary Debates, 24 Singapore Parliamentary RePorts (SPR), at cols. 1-42 (Dec. 13, 1965); 24 SPR, at cols. 770-73 (Dec. 30, 1965); 25 SPR, at cols. 237-47 (Aug. 17, 1966).

${ }^{9}$ Noor Aisha Abdul Rahman, Muslim Personal Law and Citizens' Rights: The Case of Singapore, 7 AsIAN J. ComP. L. 129-33 (2012).

${ }^{10}$ See Ayelet Shachar, Multicultural Jurisdictions: Cultural Differences and Women's Rights (2001).

${ }^{11}$ See Secularism, Islam and Modernity: Selected Essays of Alam Khunmiri (M.T. Ansari ed., 2001).
} 
society, are nevertheless deemed sacrosanct and immutable, irrespective of changing social conditions and their influence on families. No distinction is made between rulings that are the product of socio-historical conditions and their eternal underlying values. Coupled with these is fear and insecurity that the fundamentals of the faith will be compromised or the floodgates will be opened once an aspect of law is critically appraised or modified in the face of change. In their discourse, overriding emphasis is given to certainty and predictability of law as justifications for clinging on to selected rulings from the past. The basic motif reveals conception of Muslim law as an inflexible code of religious rules to be "applied in all or nothing fashion" and immune from change. ${ }^{12}$ Reluctance or unwillingness to adapt the law based on principles, taking into consideration divergent contexts and changing social conditions affecting the family, is also evident. When confronted with any novel legal thought or concept, the tendency is to evade the task of analyzing its relevance based on principles. More commonly, such a law is dismissed as "unIslamic" or "secular." Furthermore, although tampering with the adverse or harsh effects of the law on lives by employing strategies outside the scope of the law-usually suspending the law on the ground of exigency (darurah), which accords with a principle of Islamic jurisprudence-by the rigid minded is common, proactive efforts to reevaluate and revise the law are "unthought." It is not an overgeneralization to say that the prevalence of the rigid mode of thinking in Muslim law has severely hampered the prospect of its reform. Change, when it occurs, is generally imposed upon the rigid-minded rather than arising from their independent critical reflections. The result is that some aspects of the Muslim law upheld are incongruent with change that has profoundly impacted the family.

The dominance of the rigid mode of thought presents a major challenge to the prospect of the Muslim law to keep pace with societal change. Singapore's modernization and democratization efforts have paved the way for vast improvements and opportunities for the progress and development of its citizens irrespective of gender, which in turn have conditioned changing conceptions and law relating to marriage and family. The process has also been accompanied by greater significance accorded to individual rights, a phenomenon exacerbated by exponential production and dissemination of information leaving few communities isolated. ${ }^{13}$ Developments in human rights discourse and conventions, both globally and locally, and greater structural diversity of the community and its effect on valuation and the vast and dynamic developments that are taking place in family justice system in general are some of the major factors that are inevitably shaping perspectives and worldview of Muslims who do not live in isolation from these developments. Yet, given the prevalence of the rigid mind amongst dominant stakeholders and the government's approach to managing law and religion for the Muslim community, incongruence and tension between the Muslim law and intra-community competing group thought are inevitable. Amendments to the AMLA since it was implemented in 1968 have been largely confined to matters of administration, jurisdiction, and power of the Syariah Court-while slower to adapt is the substantive law. The AMLA does not generally codify the Muslim law. The law in force is largely drawn from selected rulings of classical scholars of the past, especially from the Shafie school to which the majority of Muslims in Singapore are deemed to subscribe. While competing views on the substantive law exist within the Muslim legal tradition, these tend to be marginalized given the traditionalistic leanings of the dominant group. ${ }^{14}$ The absence of right to exit from the

\footnotetext{
${ }^{12}$ Anver M. Emon, Conceiving Islamic Law in a Pluralist Society: History, Politics and Multicultural Jurisprudence, SingAPORE J. LegAL STUd. 331 (Dec. 2006).

${ }^{13}$ On the problem of rigid mode of thinking amid change, see KHALED ABOU El FAdL, SPEAKING IN God's NAME: IsLAMIC Law, Authority and Women (2001). See also Abdullah A. An-Naim, Islamic family Law in a Changing World: A Global Resource Book (2002).

${ }^{14}$ See, for instance, the debate on the Human Organ Transplantation Act of 1987, which provided for Muslims to opt-in, unlike non-Muslims who had to opt-out of the Act, should they refuse to donate. The adverse ramifications of the law on Muslims for at least three decades was conditioned by the fatwa of MUIS enunciated in 1973, which forbade the donation of human organs without qualifications, which the government deferred to in excluding Muslims from HOTA, unless they opted
} 
personal law without having to abjure the faith within this system of group accommodation presents pressing issues for members. I will discuss the difficulty in balancing group autonomy with individual rights, and the adverse impact of Muslim personal laws on individual rights in the areas of marriage, divorce, inheritance, and wealth planning in the form of trusts.

\section{Marriage}

Arising from the dual family law system and the arrangement which binds the Muslims to their personal law, marriages between Muslims can only be solemnized and registered by ROMM "in accordance with the Muslim law," which the AMLA does not define. Though the original Section 89 of the AMLA did allow for a marriage in which one of the parties is non-Muslim, presumably with a kitabiyah or kitabi (Jew or Christian), the dominance of the rigid mind long removed this possibility in practice. The amendment to Section 89 of the AMLA in 2008 effectively sealed off this possibility and reflects more accurately the law as practiced. ${ }^{15}$

Recognition of the fact that such a marriage would not have been considered a valid Muslim marriage despite the letter of the law had led to the amendment of Section 3 of the Women's Charter in consideration of the need to protect the rights and status of the parties and their offspring. ${ }^{16}$ The amended Section 3(4) of the Women's Charter, however expressly prohibits a marriage between persons who are Muslims under the Act. Thus, a Muslim couple is unable to opt for a civil marriage if they do not wish to be bound by Muslim law unless they abjure Islam. While a Muslim is permitted to marry a non-Muslim under civil law, problems may arise pertaining to succession of the estate of a deceased Muslim by his or her nonMuslim spouse or children.

Sections 111 and 112 of the AMLA stipulate that the estate of a deceased Muslim domiciled in Singapore must be distributed in accordance with Islamic law of inheritance (faraid). The Intestate Succession Act (Cap 146) does not apply to Muslims. Rigidity in mode of thinking of the law raises potential problems for beneficiaries — spouse and children-of a Muslim-non-Muslim marriage. A religious ruling (fatwa) passed by MUIS had enunciated explicitly that a non-Muslim cannot inherit the property of a Muslim, and likewise, a Muslim cannot inherit the property of a nonMuslim. ${ }^{17}$ As the children from such unions are not recognized as legitimate by another fatwa passed by MUIS, they may not even be eligible to inherit the estate of the Muslim parent even if they are Muslims.

These rulings guide the disposal of the estate of a Muslim party even when the deceased was married under the civil law. ${ }^{18}$ Applying the general principle of the Shafie school on testamentary disposition, non-Muslim spouses and their children are not entitled to more than one-third of the estate of the deceased. The strong tendency to regard the law as immutable has resulted in administrators of the AMLA appealing to the morality and compassion of Muslim beneficiaries to allow non-Muslim spouses and their children their due rights under the general law of inheritance. Yet there is no reason not to embark on systematic and proactive changes in the AMLA on the ground of Islamic values such as justice, compassion, and kindness to widows and orphans, irrespective of religious affiliation. While disputes have arisen between non-Muslim spouses and children and Muslim beneficiaries, such as parents and siblings of the deceased Muslims-or where in the absence of kin, MUIS as the custodian of community's wealth (baitulmal) is a legitimate beneficiary-these have been resolved extra-judicially. MUIS counsels Muslim beneficiaries and appeals to their moral conscience to give up their rights to the estate of the deceased

\footnotetext{
in, irrespective of competing views within the community. For an insight into the debate on the issue viz-a-viz the fatwa, see Syed Hussein Alatas, Biarkan Buta (1974).

${ }^{15}$ AdMINISTRATION OF MusLim LAW ACT $\$ 89$ (1968), https://sso.agc.gov.sg/Act/AMLA1966 [hereinafter AMLA].

${ }^{16}$ Singapore Government Printer, Report of the Select Committee on the Administration of the Muslim Law Bill (1966).

${ }^{17}$ Muslim Religious Council of Singapore, Kumpulan Fatwa, 16 (1991).

${ }^{18}$ Administration of MUSLIM LAW ACT $\$ \$ 60,111$ (1968), https://sso.agc.gov.sg/Act/AMLA1966 [hereinafter AMLA].
} 
Muslim. ${ }^{19}$ Though such efforts have tampered the harsh effects of the law, strong reluctance to revise it impedes the development of clear guiding principles that can adequately safeguard and protect the rights of beneficiaries.

Another instance of rigidity in the traditional mode of thinking is the resistance to changing the legal age of marriage. It took about four decades after the introduction of the AMLA for the age of marriage for Muslim girls to be raised from sixteen to eighteen years of age, despite vehement critique by prominent Muslim leaders in the community extending way back to 1966 on the adverse social implications of young marriages. ${ }^{20}$ Yet, delay in adapting the law to change persisted until 2008, despite the fact that Muslim law does not fix the age of marriage. Furthermore, numerous Muslim societies have raised the age of marriage as part of the modernization of Muslim family law decades earlier.

The law pertaining to the power of the wali (guardian) on the marriage of his ward or daughter is another case in point. It has remained an enforceable law today, despite significant changes in the condition of women and family. Although morally a guardian should obtain his daughter's consent or endorsement, legally, according to the Shafie school, he is not compelled to do so. ${ }^{21}$ While the law reflects the social norms and obligations of traditional society, the same cannot be said to apply in Singapore today. ${ }^{22}$ To a certain extent, change is already reflected in Section 95(3) of the AMLA, which permits a woman without a wali, or where the wali has unreasonably withheld consent, to solemnize her marriage with the approval of the kathi. However, the kathi must make full inquiry to satisfy himself that there are no lawful obstacles according to the Muslim law to the marriage. The wali can raise objections on what is traditionally regarded as lawful. Although these provisions tamper the traditional law on the power of the wali to consent to his daughter's marriage, and in most cases today, the consent of the wali or kathi has been reduced to a formality, the fact that the law continues to be preserved has not prevented contentious legal disputes brought before the kathi and appeals against his decisions by the wali. While it is true that case law since the 1980s reveals that, in most cases, judgements tend to be in favor of the women's choice of spouse against the wali's wishes, grounds of judgement continue to demonstrate lag with changing social norms. Judges often invoke public interest-stating that not approving the marriage is averse to society's well-being. ${ }^{23}$ The extent of the relevance of such considerations to the right of women remains contentious. In the recent case of Izza Amalina bte Ibrahim, the kathi declined to solemnize and register the marriage of a woman after her legal guardian had refused his consent simply because the prospective groom was from a Shia school of law, although the sect is recognized by MUIS as part of the fold of Islam. While the Board of Appeal reversed the decision and ruled in the woman's favor, its ruling reveals considerations that are not based on her right of choice of spouse. The point at issue that remains is that there has been no reform in the law on this aspect given the dominant mode of thinking amongst the administrators of Muslim law which sanctions denial of a woman's right to choose her marriage partner unconditionally, and instead subjects it to the approval of her guardian or officially appointed male agents. The rights of women in the Women's Charter in this regard are not available to Muslim women under Muslim law.

Another example is the issue of polygamous marriage, which the law preserves, though its incidence is low. Although there are regulatory measures restricting the practice, a husband has merely to satisfy the kathi that there is lawful benefit to the marriage, for instance: in cases where a wife is unable to conceive; where the husband's income and financial capacity are satisfactory

\footnotetext{
${ }^{19}$ Noor Aisha Abdul Rahman, Muslim-non-Muslim Marriage in Singapore, in Muslim-NON-Muslim MarRIAGE: PolitiCAL and Cultural Contestations in Southeast Asia 302-06 (Gavin W. Jones et al. eds., 2009).

${ }^{20}$ Ahmad Ibrahim, The legal Status of Muslims in Singapore, Malayan L. J. 64-65 (1965).

${ }^{21}$ Ahmad IBRAHIM, IsLamic LAW in MaLaya 187 (1965).

${ }^{22}$ Wael B. Hallaq, Sharia: Theory, Practice, Transformation 462-63 (2009).

${ }^{23}$ See Re Abu Samah bin Md Dros, 5 Singapore Syariah Appeals Report 31 (1990).
} 
and will not adversely affect the welfare of the families; and where a husband is able to treat his wives equitably. The consent of the first wife is not an essential factor to the outcome of the application, although she is usually summoned as a witness to assess her husband's application. Though the kathi and the Appeal Board have clearly adopted a highly restrictive approach to polygamy, the importance and priority given to factors for consideration are not transparent. On the one hand, in most cases, the first wife's disagreement with the second marriage is not considered as an important factor. The husband's financial capacity, on the other hand, is accorded greater significance. Therefore, in the case of Saheeda Banu $v$ Osman Mohamed Sabeer, ${ }^{24}$ the Appeal Board approved a husband's polygamy application even though the wife had objected to it. The Board has also rejected applications, despite agreement of the wife, when it found that the husband's salary could not reasonably provide for an additional family.

While abolishing the law may not be acceptable to religious leaders given their predominant mode of thought, the AMLA does not provide a right of exit for a wife to leave a polygamous marriage if she wishes to. Polygamy is not an independent ground for divorce in the AMLA. Currently, divorce by taklik open to women (breach of pre-nuptial agreement) excludes polygamy. Though a wife may include polygamy as a ground for divorce in this agreement, the level of consciousness of women of their rights to do so generally, and the way in which pre-nuptial agreements have been pre-determined in the marriage certificate, render this possibility remote. Furthermore, none of the nine grounds stipulated in Section 49-which allows the judge to decree a divorce-include polygamy. Section 49(vi) comes to closest to allowing divorce under polygamy, stating: "[I]f he has more wives than one and does not treat them equitably in accordance with the requirements of the Muslim law." The provision implies that unless a wife can prove that she has suffered inequitable treatment in polygamy, the law offers her no clear exit. The burden of proving "inequitable treatment" is inevitably more onerous than if polygamy itself constitutes an independent ground for divorce. The other grounds, "harm caused to wife not amounting to physical harm," as well as "any other ground recognised in Muslim law," also offer similar challenges. In fact, judicial decree of divorce has generally been confined only to cases of impotency and chronic illness.

\section{Divorce}

Apart from marriage, the laws on divorce also reflect rigid adherence to selected rulings from the past, incongruent with values of equality and non-discrimination based on gender. The persistence of the law on unrestricted unilateral divorce by husbands (talak), while wives must apply for divorce based on specific grounds stipulated in the AMLA, illustrates the point. Whereas under the Women's Charter, grounds for divorce are gender neutral and offered as a last resort when it is proven that the marital relationship has irretrievably broken down and that there are facts to suggest that it would be unreasonable for the court not to grant judgement, the Muslim divorce law has remained fixed, based on past Shafie rulings that differ radically. Here again, rigidity in the mode of thinking amongst religious leaders has led them to lean towards the position that, while the law gives a husband the unfettered right to terminate his marriage without cause, it is morally abominable for him to do so. Instead of systematically reevaluating law based on clear and common principles taking into consideration changing social conditions, they choose to mitigate the right to divorce with moral restraints. Thus, even today, a Muslim man may divorce his wife simply by pronouncement of talak. The words of an ex-President of the Syariah Court in the case of Latifah bte Hassan v. Jumari bin Yaacob ${ }^{25}$ to the effect that "it is clear that the power of talak lies in the hands of the husband who can divorce his wife whenever he wishes without cause" has remained good law. Hence, talak uttered at any time and place remains valid if it is uttered clearly.

\footnotetext{
${ }^{24}$ Saheeda Banu v. Osman Mohamed Sabeer, Singapore Syariah Appeal BoArd (Appeal No. 12/2011) (2012).

${ }^{25}$ Latifah bte Hassan v. Jumari bin Yaacob, SYARIAH COURT (148/77).
} 
Talak pronounced prior to the divorce process is also valid so long as it is uttered without ambiguity. Furthermore, it is also not an offense for talak to be pronounced outside court. Neither are there legal safeguards against arbitrary talak. Reluctance of religious leaders to reevaluate the law has been justified by the assertion that husbands who abuse the power of divorce will meet their punishment in the hereafter.

The amendment to Section 46B (1) of the AMLA in 2017 that grants a husband the choice of applying for divorce is ineffective in alleviating the problem or strengthening marriage as explicated. If the intention of this provision is to "discourage frivolous pronouncements of talak outside the Syariah Court", the provision should make clear that all pronouncements of talak out of court are not valid in the eyes of the law and should be regarded as an offense. ${ }^{26}$ Furthermore, while the amendment allows the court to summon the wife and inquire if she consents to the divorce, it also fails to make clear the effect of her consent or otherwise. The provision does not specify if the divorce will be treated as a divorce by mutual consent, whereby no ground for divorce is needed, and that her rights to consolatory gift and ancillary matters will not be affected. It is also unclear if the court has the right to order the couple to attend counseling and other activities under Section 43A, which may only prolong difficulties for both parties. The section is also silent about the effect on the wife who disagrees with the divorce. Furthermore, the effect of the provision on a husband who changes his mind after his wife agrees to the divorce is also not spelled out. Can a wife, for instance, obtain a divorce by judicial decree or fasakh (Section 49) under such circumstances? In the absence of clarity on these issues, the extent to which the amendment can be said to improve the rights of women or strengthen marriages remains contentious.

As opposed to talak, the law mandates that a woman can only terminate her marriage, even to an extremely undesirable husband, by proving a ground acknowledged in the Muslim law or by persuading her husband to release her (kholo). The most common of these are taklik, which are special conditions made by the husband after the marriage ceremony. In Singapore, they are stipulated in a standard form printed in the marriage certificate as follows: Failure on the part of the husband to maintain his wife for at least four months, causing injury to her, causing damage to her property, deserting wife for a period of four months or more, and causing wife to lose her selfrespect. If the wife complains to the Syariah Court that her husband has breached any of these conditions and her complaint is substantiated, she will be entitled to a divorce. The burden of proof, however, is high. Furthermore, the latitude to include additional conditions is remote. While divorce by judicial decree (Section 49) offers nine grounds, it is rarely applied. Though extending it to both parties will ensure gender neutrality in divorce, this prospect is "unthought" given the predominant tendency to rigidly adhere to selected rulings of the past that render divorce the prerogative of the husband. The persistence of this law in the face of change breeds gender partiality in favor of husbands. Strong justifications based on equality and justice call for this imbalance to be addressed. Even the administration of kholo (divorce by redemption) has its drawbacks, which undermines the balance of unreserved talak. While it has been opined that kholo provides the surest safeguard for release by wives when her marital life is wrecked, Section 47(2) of the AMLA suggests that the husband must consent to the divorce. If he refuses to allow the divorce, the matter will be referred to arbitration (hakam). ${ }^{27}$ Male arbitrators appointed by both parties would have to advise the husband to pronounce the talak to his wife, or the court may direct the husband's appointed arbitrator to pronounce the talak on his behalf. Therefore, though women do eventually succeed in obtaining divorce by kholo, the processes

\footnotetext{
${ }^{26}$ Yaacob Ibrahim, Minister for Communications and Information, Minister-In-Charge of Cyber Security, and Minister-InCharge of Muslim Affairs, closing speech at the second reading of the Administration of Muslim Law (Amendment) Bill in Parliament, Strengthening the Administration of Muslim Law Act (Aug. 1, 2017), https://www.mccy.gov.sg/about-us/newsand-resources/parliamentary-matters/2017/aug/strengthening-the-amla.

${ }^{27}$ AMLA $\$ 50$.
} 
involved are intertwined with the husband's approval. Delays and additional costs with the appointment of hakam also work to their disadvantage.

\section{Inheritance}

The administration of the Muslim personal law governing distribution of Muslim estates that binds Muslims without their choice presents further challenges to members of the community who, for reasons best known to themselves, may wish to resort to other legal arrangements provided by civil law. As mentioned, the estate of a deceased Muslim in Singapore must be distributed in accordance with the Muslim law of inheritance. While a Muslim can dispose of his property by will, he is subjected to the Muslim law. ${ }^{28}$ For the majority, the Shafie ruling on testamentary bequest is that it should not exceed one-third of the estate and cannot be made in favor of any of the legal heirs. The remaining two-thirds must be distributed amongst his legal beneficiaries as prescribed by Islamic law. The Syariah Court, which is empowered to issue a Certificate of Inheritance, certifies the persons entitled to a share in the estate of a deceased Muslim. ${ }^{29}$ It is submitted in applications for grant of probate or letters of administration which are made to the Family Justice Court, as the Syariah Court does not have the jurisdiction to hear such applications. Beneficiaries under faraid are surviving spouses, children, and parents, according to a prescribed precedence and proportion. When there are no male heirs, part of it goes to baitulmal. Sons are entitled to double the share of daughters. The law as interpreted clearly does not permit gender equal distribution of the estate. Its binding effect on Muslims removes any possibility for them-unless with the consent of all beneficiaries - to vary the distribution of the estate according to their wishes and what they consider just or reasonable, as well as national laws and policy considerations governing property and public housing, which affects Singaporeans as a whole.

Due to these factors, Muslims have resorted to other ways of disposing their estate that depart from the Muslim law. One of these is the joint tenancy scheme based on the common law, which presumes the right of survivorship of the remaining tenant when the other passes on. Most of the properties involve subsidized public housing which impose restrictions on second time buyers. In 1998, MUIS published a fatwa that joint tenancy is incompatible with the faraid, as the jointly owned property cannot become an absolute property of the surviving spouse, who is entitled only to a half share of the value. The remaining half share is to be distributed in fixed shares amongst the legal beneficiaries, as prescribed in faraid. In response to pressures encountered by survivors to sell their properties imposed by beneficiaries under faraid contesting their interest in the property, MUIS introduced alternative so-called Islamic instruments to harmonize civil and religious law, while at the same time providing an option for Muslims who wish to follow the law of faraid. While still not recognizing joint-tenancy agreements as valid in Islam, the two instrumentshibah ruqbah (revocable gift) and nuzriah (vow made to give one's wealth, in full or part, to another party before death) - were believed to convey the intention that the jointly held property was to vest in the surviving joint tenant upon the death of the other. The instruments were to serve as an expression of religious intent by the joint tenant, and its effects on ownership were deemed by the Legal Committee to be like the concept of right of survivorship. As the Committee asserted, while "there is a dichotomy between 'civil law' and 'Islamic law' that seems to be maintained, yet what separates the two seems more the form than the spirit and substance." 30 Yet if such is the case, one wonders why the objection to joint tenancy persisted. How the hibah-ruqbah differs from a will was not explicated. Furthermore, validity of the nuzriah was questioned in the judgement of the case of Mohamed Ismail bin Ibrahim v. Mohd Taha bin Ibrahim Mohamed. It was affirmed that nuzriah does not appear in any treatises nor can it be attributed to any

\footnotetext{
${ }^{28}$ AMLA $\$ 111(2)(a)$.

${ }^{29}$ AMLA $\$ 115$.

${ }^{30}$ Fulfilling the Trust: 50 Years of Shaping Muslim Religious Life in Singapore 70 (Norshahril Saat ed., 2018).
} 
Muslim scholar. An expert witness from Malaysia who was consulted by the court had also maintained that the concept was neither known nor practiced by Muslims of the Shafie school in the region. Its formulation to the effect that the property had to be given away to proposed devises three days or an hour before the death of the testator was also said to be "a fiction which poses a puzzle of epic proportions that no mere mortal can ever hope to resolve." 31

The confusion over the legality of joint tenancy for Muslims was put to rest with the judgement of the Court of Appeal in the case of Shafeeq Salim \& Anor v. Fatimah bte Abd Talib. ${ }^{32}$ The court ruled that Section 112(1) of the AMLA was concerned with the distribution of the estate of a Muslim person and not with the determination of the assets that constitute the estate. This was to be made under the common law and not Muslim law. With the land in question not being part of the estate, the right of survivorship in the joint tenancy applied. The court also commented that the fatwa of MUIS was inconsistent with general law.

Despite the Appeal Court's judgement, problems persisted as MUIS continued to promote the nuzriah and Muslims continued to create it to ward off potential disputes by beneficiaries claiming an interest in the estate against the surviving joint tenant. It entailed additional costs, not to mention the inconvenience caused in preparing these instruments, which would not likely stand in case of a dispute in the civil court. While their action may illustrate the power of fatwa in conditioning religious understanding amongst Singapore's Muslims, it also clearly signified that they do want to vary how their estate is distributed. Such a motive does not mean disregard for the faraid. On the contrary, they may differ on how the law should be construed given Singapore's context and the changing socio-economic conditions. Even the fatwa of MUIS is an attempt at adjusting the faraid to change. ${ }^{33}$ Their nuzriah, however, is fraught with traditionalism. This remote instrument is believed to have been practiced in the past and the preconditions imposed on it to be valid-it calls for two male Muslim witnesses who have not committed major sins or repeated small sins - illustrate the point. That MUIS continued to promote nuzriah despite the judgement of the Superior Court further illustrated rigidity of thought and its adverse ramifications on Muslims. It was only in May 2019, two decades after the fatwa invalidating joint tenancy under Muslim law was passed, that MUIS has reversed its position and enunciated in its revised fatwa that hence, nuzriah and hibah ruqbah are no longer required to validate it. ${ }^{34}$

\section{Wakf (Charitable Endowment) and Wealth Planning}

The adverse implications on Muslims arising from the arrangement which binds them to their personal law is also manifested in the matter of wakf (charitable endowment). Devised for charitable purposes for the benefit of the community (wakf am), or as trusts for family endowment (wakf khas), wakf were previously vested in the Muslim Endowment Board. Since the inception of the AMLA, these trusts are vested in MUIS, though trustees may be constituted to manage them. ${ }^{35}$ Any wakf not validated by MUIS is presumably void. Muslims in Singapore also cannot create family wakf with a value of more than one third of the value of their estate.

The provision of the AMLA imposes controls on wakf khas, which may be construed as inhibiting the Muslim citizens' rights to deal with their property, while non-Muslims are not subject to similar laws. It has been argued that wakaf in its charitable and family permutations is a trust, and thus every individual Muslim should have the right to create his or her own private trusts to be treated and handled by the common law. While the provisions in the AMLA may have been necessary to safeguard abuses in the management of wakf in the past, there are now other relevant

\footnotetext{
${ }^{31}$ Mohamed Ismail bin Ibrahim v. Mohammad Taha bin Ibrahim, 4 SLR 756 (2004).

${ }^{32}$ Shafeeg bin Salim Talib v. Fatimah bte Abud bin Talib, SGCA 11 (2010).

${ }^{33}$ Norshahril SaAt, Fulfilling the Trust: 50 Years of Shaping Muslim Religious Life in Singapore 67-70 (2018).

${ }^{34}$ https://www.muis.gov.sg/officeofthemufti/Fatwa/English-Joint-Tenancy

${ }^{35}$ AMLA $₫ 58(1)$.
} 
statutory laws and regulations legislated to safeguard the society's charitable institutions and their funds, and Muslim charitable endowment like wakf could be subjected to such laws and regulations. Another issue with the arrangement is that wakf vested in MUIS is handled according to the aims and objectives of MUIS as an organization. The recent amendment to the AMLA further strengthens MUIS' power over the appointment and removal of trustees of the wakf properties. Though the board of appointed trustees is still allowed to manage the wakf, the fact that the legal title is still with MUIS means that MUIS holds power over it. This may have the effect of marginalizing the intention or rights of the settlor. Presently, Wares Investment Pte Limited, wholly owned by MUIS, runs many wakf properties vested in MUIS or controlled by it. How they are administered or disposed of is not entirely known given lack of transparency in these areas. This could possibly account for the lackluster private initiatives in the creation of new community and private wakf over the last several decades, although the community is becoming more affluent. It has thus been strongly suggested that, given the more developed Malay-Muslim community today, the law regulating wakf should be revaluated. Though there may be some concerns with the use of wakf on national security, MUIS could still be a regulatory body to audit and inspect the running of wakf without mandating that its legal title vests with it. ${ }^{36}$

\section{Accommodating Muslim Personal Law and its Effect on Gender Equality}

The arrangement that makes the Muslim personal law binding on the Muslims further complicates efforts to bring about gender equality, even where this is supported by a segment of the community. Notably, Singapore is a signatory to the Convention of the Elimination of Discrimination Against Women (CEDAW) but has entered partial reservations to Article 16, which deals with the elimination of gender discrimination in the domain of marriage and family relations-more specifically Articles 1(a), (c) and (h) on the basis of the need to accommodate personal laws.

The full text of the article reads:

1. States Parties shall take all appropriate measures to eliminate discrimination against women in all matters relating to marriage and family relations and shall ensure, on a basis of equality of men and women:

(a) The same right to enter marriage;

(b) The same rights and responsibilities during marriage and at its dissolution;

(c) (h) The same rights for both spouses in respect of the ownership, acquisition, management, administration, enjoyment and disposition of property, whether free of charge or for a valuable consideration. ${ }^{37}$

Inevitably, the state has also abstained from ratifying Article 2, which compels signatory states to undertake as a matter of urgency measures designed to achieve substantive equality and equal access to those opportunities. The government explicated that in the context of Singapore's multiracial and multi-religious society and the need to respect the freedom of minorities to practice their religious and personal laws, it reserves the right not to apply Articles 2 and 16 where compliance with these provisions would be contrary to their religious and personal laws. This standpoint is also deemed necessary to maintain the delicate balance of Singapore's multi-religious society. ${ }^{38}$

\footnotetext{
${ }^{36}$ Refer to Abdul Rahman BMH, Majelis Ugama Islam Singapura and the Administration of Muslim Law Act: A Critical Review (2008) (unpublished Academic Exercise), Faculty of Law, National University of Singapore.

${ }^{37}$ Convention on the Elimination of All Forms of Discrimination Against Women, Dec. 18, 1979, 1249 U.N.T.S. 13, https:// www.un.org/womenwatch/daw/cedaw/text/econvention.htm\#article16 [hereinafter CEDAW].

${ }^{38} \mathrm{https} / / /$ documents-dds-ny.un.org/doc/UNDOC/GEN/N00/282/95/IMG/N0028295.pdf?OpenElement
} 
Consistent with its approach to managing the religious affairs of its minority Muslim community, the government has deferred to the dominant officially appointed Muslim religious elite for its official standpoint. As in other Muslim states, the Muslim elite in Singapore subscribes to the view that the Muslim laws regulating marriage, divorce, and inheritance are incompatible with the demands of equality and non-discrimination. More specifically, these refer to: The right of a husband to terminate his marriage unilaterally (talak), unlike a wife who is required to prove a ground for divorce; a husband's right to polygamy albeit subject to several restrictions; the requirement of the consent of a wali or guardian for the bride to marry; the legal obligation of a husband to maintain a family; and the greater share of the estate of a deceased for sons and paternal male kin over daughters. They maintain that Sharia law on these issues is not based on equality but instead complementarity of rights. Thus, a husband's obligation to maintain his wife is, for example, balanced by his unilateral right of divorce (talak). ${ }^{39}$ Similarly, the obligation of sons and other male relatives to maintain the family is said to provide the basis for their entitlement to a larger share of the estate. This justification is at odds with change. Like their non-Muslim counterpart in Singapore, Muslim women's involvement in the labor force has advanced incredibly, rendering the traditional law on reciprocity of obligations and rights incongruent with reality. The law carried over from the past is also severed from the traditional social system, where customary norms and sanctions compel male relatives to maintain parents and sisters. This can no longer be enforced. Insisting on such law formulated in the past despite changing social conditions not only reinforces the narrative that the Muslim law is gender unequal and patriarchal, but also that it is supra temporal and beyond modification.

It is also pertinent to reiterate that even the religious elite is not completely able to fend off the tide of change. Given their dominant mode of thinking on the law, however, they tend to be reactive rather than embark on systematic revaluation of the law. Thus, the outcome is marred by inconsistencies. The fatwa on nuzriah discussed above illustrates the problem. It provides a strong indication of the intent of the Legal Committee of MUIS to alleviate the adverse implications of the literal application of the faraid in dealing with the estate of deceased Muslims in contemporary Singapore. Instead of embracing the joint tenancy scheme on grounds of commonality of principles and values between Islamic law and common law, however, the fatwa attempted to tamper the faraid by way of remote "Islamic" instruments that are contentious.

Ensuring gender equality, including removing the reservations to Articles 16 and 2 of CEDAW, provides the prospect of giving effect to the wishes and preferences of Muslims today. Such efforts have been spearheaded by prominent Indonesian scholars, such as Hazarin, Sjadzali, and Yahya Harahap, who promoted equal division of estate for sons and daughters as consonant with the bilateral kinship system and contemporary realities of Indonesian society. Their efforts have been given greater impetus with the Counter Legal Draft advocated by some Indonesian scholars and activists as part of the efforts to reform the Muslim law in tandem with changing Indonesian society. ${ }^{40}$ Muslims in Singapore are not isolated from such developments. The state's cautious approach in partially ratifying Article 16 based on the legal opinion of the religious leaders on Muslim law has, however, dampened the opportunity for rethinking the law. While it has opened greater pathways for Muslims to resolve matrimonial issues and enforce Syariah Court orders in the Family Justice Courts, it continues to preserve the arrangement of compelling Muslims to their personal law regime despite diverse understanding of the law evident in the practice of the community.

\footnotetext{
${ }^{39}$ Michele Brandt \& Jeffrey A. Kaplan, The Tension between Women's Rights and Religious Rights: Reservations to CEDAW by Egypt, Bangladesh and Tunisia, 12 J. L. \& ReLigion 105, 109-10 (1995).

${ }^{40}$ See Euis Nurlaelawati, Modernization, Tradition and Identity: The Kompilasi Hukum Islam and Legal Practice in the Indonesian Religious Courts 75-84 (2010). On developments posed by the Counter Legal Draft, see Marzuki Wahid, Pembaharuan Hukum Keluarga Islam Pasca Ode baru dalam Pendekatan Politik; Studi Kasus CLD-KHI, in Generasi Baru Peniliti Muslim. Indonesia. Kajian Islam dalam Ragam Pendekatan (Wahid \& Mukhtar eds., 2010).
} 
The state's failure to commit fully to gender equality for Muslims has adverse implications on Muslim women. It reinforces the status quo and dominant a-sociological and a-historical reductive claims that the Muslim laws undermine gender equality, while the crux of the problem-for example, the orientation, outlook, or perspective of the dominant administrators of the law-is overlooked or obscured. Though the state's partial reservation to CEDAW was justified positively as embodying the principle of accommodation of minority rights, the implications are averse to the interests of members of the community, especially women.

\section{Influence on the Syariah Court}

There are also other compelling reasons for why the Muslims should be granted the choice of law applicable to them. It cannot be denied that the Syariah Court is not on par in terms of status and developments compared to the Family Justice System. Administered by the Ministry of Culture, Community, and Youth, the Syariah Court tends to be marginalized from larger developments and reforms that have been taking place in the Family Justice Courts. Though there have been many improvements in professionalism and quality of services rendered by the court, especially since 2000, these surely cannot be compared to the vibrant structural and institutional developments and reforms in the Family Justice Courts pursuant to the Family Justice Act of 2014. Enacted primarily based on recommendations of the Committee for Family Justice-formed in 2013 to review how the state's family justice system can better address the needs of youths and provide alternative dispute resolution for families in distress - the Act has ushered substantive reforms informed by evidence-based perspectives on the adverse impact of divorce on those involved, especially children. The Family Justice Courts now deal with all family related cases under a specialized body of courts. Recognizing the limits of conflict resolution from a purely legal dimension for family disputes, the courts have drawn upon knowledge from the social sciences and work closely with government and community partners to develop an ecosystem that can support and safeguard the welfare of parties and children in divorce. A gamut of familyspecific services is provided by a team of experts, for example, judges, lawyers, and other related services professionals with relevant specialized training to strengthen and enhance their familyspecific skills. ${ }^{41}$ To safeguard children's well-being in high-conflict divorce cases, a child representative scheme helps ensure that the wishes and best interests of the children are safeguarded. They interview the children, parents, and caregivers and are present at final hearings to explain court orders to the child. More upstream measures are undertaken to reduce the adverse effects of acrimonious disputes, such as maintenance claims, to benefit the children. ${ }^{42}$ These dynamic reforms are not fully replicated in the Syariah Court. Though not totally isolated from these developments, not being fully integrated into the Family Justice Courts limits the extent to which these resources and reforms can effectively benefit the Syariah Court.

\section{E. Religious Revivalism and Expanding Conservatism}

Compounding the above factors that warrant Muslims to be given the right to choice of law is the growing influence of religious revivalism amongst some segments of the emerging Malay middle class, whose activism and discourse are notably manifested in the domain of law. The phenomenon, which emerged since the 1970s, has intensified over the decades and poses a major threat to

\footnotetext{
${ }^{41}$ For a good account of the reforms implemented in the FJC, see Kevin $\mathrm{Ng}$ et al., Family Justice Courts-Innovations, Initiatives and Programmes: An Evolution over Time, 30 SING. ACAD. L. J. 617-46 (2018).

${ }^{42}$ Lee Li Ying, Family Justice Committee Aim to Provide More Upstream Support Services, Channel News AsIA (Feb. 28, 2018), https://www.channelnewsasia.com/news/singapore/family-justice-committee-aim-to-provide-more-upstream-support-9999144.
} 
the well-being of the community by its insistence on a more dogmatic, puritan, and authoritarian type of Islam and Muslim identity.

As a mode of thought, resurgence depicts a fixation with forms at the expense of underlying values and principles, and the Muslim law is one of the major areas in which this limitation is evident. Proponents are preoccupied with a fixed system of law which they assert is integral to Muslim way of life. One of the platforms used to articulate their views on Islamic law is a prominent non-governmental organization called PERGAS (Singapore Islamic Scholars and Religious Teachers Association). Almost all of the religious leadership including members of MUIS' Fatwa Committee are also members of PERGAS. Unlike the traditionalists, however, they are not concerned with the preservation of the Muslim law that has been transmitted from classical savants of the past. Instead, they seek to revive an obscurantist body of law alienated from the Muslim tradition and practices in Singapore.

Similar to like-minded counterparts such as PAS in Malaysia and the Majelis Ugama Islam Indonesia, resurgents import conservative views to justify their demands. They are generally averse to human rights, gender equality, religious pluralism, freedom of belief, and other fundamental liberties. Fatwa proclaimed by these groups that label or denounce competing groups as "deviant" or "liberal" in the pejorative sense are imported by them, shoring moral panic against such influences as threatening and undermining the unity of the community. ${ }^{43}$ The heightening of resurgence puritan interpretation of Islam centered on the scare of secularism and binary between Islamic and secular law loomed large in the attack against the appointment of a civil law trained legal practitioner as president of the Syariah Court in 1992. Though it was carried out in the sole name of a prominent local theologian in the community, it is not unreasonable to assume that his vehement criticism is not an isolated one given his wide influence and positive reputation within the community. The attack was also one-sided, as it overlooked the composition of the members of the Appeal Board, many of whom were trained in civil law without expertise on Syariah law. They frequently chaired the Appeal Committee, apart from theologians.

The negative attitude towards the civil law and the courts irrespective of commonality of values underlying both in many respects and their long-standing interaction on specific issues was also evident in PERGAS' contestations to the proposed amendments to the AMLA in 1999. A major provision of the bill, if approved, would result in concurrent jurisdiction between the Syariah Court and the High Court to hear and determine issues relating to custody of children and matrimonial property division and distribution. It would effectively allow Muslim parties the choice of having these disputes heard and determined in the High Court, if both parties agreed, or with the consent of the Syariah Court if one objects. Here, again, PERGAS was one of the major groups which vehemently registered its objections to the proposed amendment. Its major contention was that giving a choice to Muslims to resolve those issues in the High Court would result in weakening the power of the Syariah Court, which would surrender an important area of its jurisdiction to the High Court. Underlying assumptions of conflict of principles and values between Muslim and civil law were no less evident in the debate. ${ }^{44}$ In response to

\footnotetext{
${ }^{43}$ See the letter to the Straits Times by the President of the Singapore Islamic Scholars and Religious Teachers Association (PERGAS) against the Institute of Southeast Asian Studies (ISEAS) for inviting Zainah Anwar, then leader of Sisters in Islam, a Malaysian NGO, and Ulil Abshah, Head of Research and Human Resource of Nahdatul Ulama and founder of Jaringan Islam Liberal, to speak at its Regional Outlook Forum. Mohamed Hasbi Hassan, Iseas Speakers were Controversial Figures, STRAITS Times, Jan. 25, 2003, at 30. See also the recourse to MUI and state fatwa committees in Malaysia on the issue of greeting nonMuslims in Muhammad Haniff Hassan \& Mustazah Bahari, A Balance Approach to the Issue of "Merry Christmas" Greeting by Muslims, PERGAS: WASAT (Feb. 1, 2019, 2:45 AM), https://blog.pergas.org.sg/cpt_wasat/a-balance-approach-to-the-issue-ofmerry-christmas-greeting-by-muslims/.

${ }^{44}$ At the tabling of the Select Committee report on the amendment bill, the Minister in charge of Muslim Affairs, Abdullah Tarmugi, acknowledged that the proposed amendments allowing civil courts to hear ancillary matters of Muslim divorces have led to strong opinions from the Muslim community. Of the thirty-one representations received, eighteen had reservations about or were against the amendment providing explicitly for the civil courts to hear matters ancillary to Muslim divorces. Singapore Parliamentary Debates, 70 Official Reporter at cols. 1249-50 (Apr. 15, 1999).
} 
the question posed by a member of the Parliamentary Select Committee as to whether it would be fair for a secular government to allow Muslims to avail themselves to the civil court to resolve those issues, PERGAS retorted: "The purpose of AMLA was for Muslims and those who were married under the Muslim law. If we allow matters relating to Muslims to be considered in another court, we are allowing them to do something which is against the religious law ...." When informed that Muslims have been resolving specific matrimonial issues in the civil court, such as maintenance disputes, PERGAS asserted that " $[t]$ hey went there because they were ignorant that these are laws contrary to Islamic law."

PERGAS' fixation with forms as opposed to values was also evident in their concern that the High Court would award custody to parties who have renounced Islam. ${ }^{45}$ This is true even though the overriding principle governing the Muslim law on custody, like the civil law, is the paramount welfare of the child. In fact, prior to the amendment, the Syariah Court and Board of Appeal had awarded custody orders to mothers despite the fact that they had renounced Islam based on this overriding principle. ${ }^{46}$ Its vehement attack against those who attempted to give Muslims a choice in matters which religious law has adequately and exclusively provided for as tantamount to a "display of intolerance for the religion itself" provides yet another example of its defensive and authoritarian streak. ${ }^{47}$ Such concerns were not confined to PERGAS. A study reveals that "even some religious scholars (ulama) in MUIS opposed the amendments and supported PERGAS from behind the scenes due to constraints the faced as civil servants." 48 Ideological motive against the proposed amendment, seen as undermining their traditional domain of influence, cannot be overlooked. Such concern failed to consider the rights of the parties and their children's well-being. In fact, prior to the amendments, custody and matrimonial property issues have all the while been heard and determined by the High Court while divorce proceedings were pending in the Syariah Court without objections from Syariah Court judges and though the Syariah Court had exclusive jurisdiction on these matters. The amendments would merely institutionalize what had been going on empirically. Moreover, such cases have not been met with objections by litigants or the general Muslim public, which strongly implies that their overriding interest is to have their cases resolved fairly and expediently.

The resurgence mode of thought also plants the seed for exclusivism and alienation of Muslims, not only from their own competing legal tradition, but from the national law and institution. They condition Muslims not only to refrain from partaking and developing common institutions based on universal values and principles but set them apart based on their rhetoric of a pristine Muslim legal system and identity. Their reservations towards "secular" law and legal systems breeds distrust, ambivalence, and misunderstanding even if they are unable to alter these institutions radically. Despite the adverse impact on the well-being and development of the community, the danger posed by the resurgence is that it continues to gain credibility, expand, and sustain its influence in the context of insecurity and rapid change.

\footnotetext{
${ }^{45}$ Report of the Select Committee on the Administration of Muslim Law (Amendment) Bill, Bill No. 18/98, 181 (1999).

${ }^{46}$ See, for instance, the case of Heng Hock Kim, Lena (alias Lena bte Abdullah) v. Mohd Zaini bin Salleh, SGAB (Appeal No. 21 of 1998) in which the BOA submitted:

[W] e appreciate the concern of the husband, it is in the interest of the children and in the interest of the ummah that they should be brought up as Muslims. However, we do not think that evidence points towards the children being brought up as non-Muslims ... by the wife. We note the affidavit of the wife ... which should dispel the husband's fear that the wife would turn the children away from Islam ....

The Board also highlighted that: "It is apparent, however that all rules of Muslim law relating to guardianship and custody of the minor children are merely the application of the principle of benefit of the minor to diverse circumstances. The welfare of the minor children remains the dominant consideration ...." See also the case of Zakaria bin Abu Kassim v. Natasha Chooi Abdullah and Chooi Lye Chan, SGAB (Appeal No. 6 of1993).

${ }^{47}$ Report of the Select Committee on the Administration of Muslim Law (Amendment) Bill, Bill No. 18/98, 153-65 (1999).

${ }^{48}$ Mohamed Nawab Mohamed Osman, The Religio-Political Activism of Ulama in Singapore, 40 INDONESIA AND THE MALAY WORLD 1 (2012).
} 
The adverse effect of such developments on the present legal arrangement that binds Muslims to their personal law requires critical attention, all the more so given the dearth of research on the problem. Prevailing critique leans towards demonstrating how the AMLA reflects the state's overarching and authoritarian regime over the Muslims based on co-optation of sponsored elites into key Muslim institutions. The strategy is deemed to arrest the development of the Muslim law. The postulation that the state has kept Islamic law to the sphere of private law by "systematically establishing a web of interlocking state institutions with decisive interpretative authority regarding law for Muslims in Singapore and a monopoly on its enforcement which has curbed the expansion of Islamic law and re-thinking of the Anglo-Malay Madhab" is one such example. ${ }^{49}$ Overlooking how the state's approach to managing law and religion for Muslims has impacted Muslims' rights and well-being is also evident in prevailing discourse that focuses on contestations among stakeholders in representing the community's interests to the government. PERGAS being independent of the government, for example, has been pitted against MUIS as a more effective group to counter-the government's hegemonic influence and advance the interest of the community. ${ }^{50}$ Officials within MUIS have now and again been accused of being lackeys of the government. ${ }^{51}$ These narratives, which focus on the MUIS as an instrument of the state, fail to identify the real impediment in the development of the Muslim substantive law and rights of Muslim as citizens.

\section{F. Conclusion}

Given the dominance of traditionalist administrators of the Muslim law, the growing influence of religious resurgence in this domain, and competing perspectives on religion and law within an increasingly diverse community, the need for rethinking and revaluation of the system which binds all Muslims to the personal law is imperative. The fact that the Women's Charter and the Family Justice System has developed an eco-system more in tandem with change has also increased expectations of some Muslims that the present approach to law and religion needs to be reviewed. This means simply that the government should not essentialize the community as monolithic and over-rely on any dominant group to determine Muslim law simply for pragmatic reasons or even based on the presumption that to do so is in the interest of and respect for the minority community.

While the current arrangement may be deemed as accommodating the aspirations of a religious community to be governed by the personal laws, it is to the detriment of the status and rights of individuals in the community who seek to be treated as equal citizens and believe that what the state deems good for its non-Muslims citizens should be beneficial for them as well. Delegating religious affairs and law to the community to decide subjects even those who disagree with certain interpretations of Muslim personal laws to its regulatory force. It is pertinent that the state should not exclude the Muslims from any legislation based on their personal law in the interest of national integration and citizenship. This will go a long way towards not only protecting the rights and well-being of the Muslims against the effect of both the rigid minded traditionalists as well as the conservatism of the resurgence, but also ensuring greater integration amongst citizens based on commonality of laws and principles.

To address the unwarranted dilemma faced by those who want exit from the Muslim personal law without abjuring Islam, the Muslims should be given the unconditional right to be subjected to the Women's Charter if they choose to. The Charter needs to be amended to recognize marriage between Muslims unconditionally. This would mean that Muslim parties can opt for a civil

\footnotetext{
${ }^{49}$ Tim Lindsey \& Kerstin Steiner, Islam, Law and State in Southeast Asia 52 (2012).

${ }^{50}$ Kamaludeen Mohamed Nasir \& Khairuin Aljunied, Muslims as Minorities: Histories and Social Realities of MUSLIMS IN SingaPORE (2009).

${ }^{51}$ Refer to Norshahril SaAt, Faith, Authority and the Malays: The Ulama In Contemporary Singapore 42 (2015). See also Hussin Mutalib, Singapore Malays: Being Ethnic Minority and Muslim in a Global City State 89 (2012).
} 
marriage, as is the case of India. This approach will also enable the state to ratify Articles 2 and 16 of CEDAW without having to make exceptions for Muslims. Similarly, the Intestate Succession Act should also be modified to apply to Muslims without exception. Those who wish to be subjected to the faraid can create a bequest to that effect. Sections 111 and 112 of the AMLA should therefore be amended accordingly. This was in fact the position until the introduction of the Muslim Amendment Ordinance in 1960 (no. 40 of 1960) prior to Independence. ${ }^{52}$ Such changes would mirror the impending law in Western Thrace, Greece, which, when effected, would make the Muslim personal law, that has continued to bind the Muslims since independence after more than four centuries under Ottoman rule, optional for Muslims. The change is conditioned by a clash between Muslim and Greek laws on the issue of inheritance and the extent of Muslim law conformity to human rights. ${ }^{53}$

Giving Muslims the right of choice of law will not affect those who wish to remain bound by the Muslim personal law. It is not analogous to the proposed civil marriage law for all that was propounded by some Indian intellectuals after Independence in lieu of Article 44 of the Indian Constitution. ${ }^{54}$ The proposal is also not a call for the Women's Charter to be applied to all Muslims, as had been strongly articulated by Singapore's first Attorney General, Ahmad Ibrahim, shortly after Independence. In response to Muslims' demand for separation of laws, Ahmad had urged Muslims to accept the Women's Charter, which he hailed as a model piece of legislation that embodied both the standards of the Universal Declaration of Human Rights and fundamental Islamic values in the interest of their well-being and the development of a national consciousness that transcended race and religion. ${ }^{55}$ The Charter was also strongly supported by Muslim parliamentarians who saw it as progressive and beneficial to women and families. ${ }^{56}$ His proposal was, however, rejected by the dominant Muslim elite.

Giving Muslims the right of choice of law should not be seen as an attack on Muslim law. On the contrary it may result in its development. Codifying guiding principles in key areas in the AMLA would go far to curb the adverse impact of traditionalism and conservatism in the application of the substantive law. ${ }^{57}$ Apart from this, alternative institutions authorized by the state, including arbitration based on Muslim law, may also serve useful. ${ }^{58}$ The latter may also tamper and alleviate intra-community contestations for power while allowing Muslims who choose to be bound by the Muslim law to benefit from a variety of interpretations that would accompany such initiative, unlike what is currently the case.

\footnotetext{
${ }^{52}$ Noor Aisha Abdul Rahman, Muslim Personal Law and Citizens' Rights: The Case of Singapore, 7 AsiAn J. Comp. L. 129 (2012).

${ }^{53}$ Helena Smith, Greece's Muslim Minority Hails Change to Limit Power of Sharia Law, GuARDIAN (Jan. 11, 2018, 6:56 AM), https:/www.theguardian.com/world/2018/jan/10/historic-step-greek-pm-hails-change-to-limit-power-of-sharia-law.

${ }^{54}$ For some insights into this discourse, read TaHIR MaHMOOD, AN INDIAN Civil Code AND IslamiC LAW (1976).

${ }^{55}$ Ahmad Ibrahim, Special Rights for Muslims, in The Legal Status of Muslims in Singapore (1965).

${ }^{56} 12$ Singapore Legislative Debates (SLAD), at col. 463 (1960).

${ }^{57} \mathrm{See}$, for instance, the assimilation of guiding factors in determining division of matrimonial property from Section 106 of the Women's Charter into Section 52(14) of the AMLA in 1999.

${ }^{58}$ Emon, supra note 12, at 253-54 (suggesting the possibility of a government-regulated civil society sector that can address the social and religious needs of the Muslims and support greater accommodation of Muslim minorities within multicultural societies, unlike the case of MUIS which has a monopoly over the religious affairs and law for Muslims in the country).
}

Cite this article: Abdul Rahman NA (2019). Muslim Personal Laws and the Accommodation of Minorities: The Need to Better Balance Individual Rights and Group Autonomy in Singapore. German Law Journal 20, 1079-1095. https:// doi.org/10.1017/glj.2019.71 